\title{
Evaluation of Different Rates of Ampligo Insecticide against Fall Armyworm (Spodoptera frugiperda (JE Smith); Lepidoptera: Noctuidae) in the Coastal Savannah Agroecological Zone of Ghana
}

\author{
Michael Y. Osae, Justice O. Frimpong, Joshua O. Sintim, Benjamin K. Offei, Dinah Marri, \\ and Selorm E. K. Ofori \\ Biotechnology and Nuclear Agriculture Research Institute, Ghana Atomic Energy Commission, P. O. Box L.G. 80, Legon, \\ Accra, Ghana \\ Correspondence should be addressed to Selorm E. K. Ofori; selormofori@yahoo.com
}

Received 27 September 2021; Revised 29 December 2021; Accepted 13 January 2022; Published 29 January 2022

Academic Editor: Durgesh Jaiswal

Copyright (c) 2022 Michael Y. Osae et al. This is an open access article distributed under the Creative Commons Attribution License, which permits unrestricted use, distribution, and reproduction in any medium, provided the original work is properly cited.

\begin{abstract}
The destructive nature of maize fall armyworm has triggered the importation of plenty of plant protection products onto the Ghanaian agrochemical marketplace. These imported chemicals sold at market places sometimes are unregistered for use in the Ghanaian environment. Thus, some importers do not do due diligence in testing the chemical agronomically to ascertain its mode of action and also being not harmful to beneficial insect species in the Ghanaian environment. It was in this view that three Ampligo concentrations or rates $(0 \mathrm{ml} / \mathrm{ha}, 200 \mathrm{ml} / \mathrm{ha}$, and $240 \mathrm{ml} / \mathrm{ha})$ were tested against $\mathrm{FAW}$ on maize that were sown at a spacing of $60 \mathrm{~cm} \times 60 \mathrm{~cm}$. Treatments applied to maize were arranged in a randomised complete block design and replicated three times. Ampligo rates caused a very significant $(p<0.05)$ reduction in FAW at 21 and 28 days after maize emergence. The damage to maize leaf on treated maize plot was significantly $(p<0.05)$ different from that on the untreated. Thus, damage of FAW was more visible on maize leaves on control plots compared to the treated ones. A significantly $(p<0.05)$ positive correlation existed between damage rating and FAW number. Furthermore, the Ampligo rates correlated negatively to FAW density at $p=0.014$ at 21 days after emergence. Also, FAW infestation did not impact maize grain yield. The study, therefore, concluded that Ampligo pesticide falls in low-risk plant protection product category with a very potent active ingredient that reduces FAW populations. We recommend that Ampligo should be applied between 14 and 21 days after emergence; two applications at one-week interval at $200 \mathrm{ml} / \mathrm{ha}$ are sufficient to sustain maize for the whole cropping season.
\end{abstract}

\section{Introduction}

The fall armyworm (FAW; Spodoptera frugiperda (JE Smith); Lepidoptera: Noctuidae) is a moth that is native to the Americas. It is perceived to be one of the most devastating crop pests in the Americas as it feeds on different crop species. Apart from maize, which is its main host, it feeds on crops such as sorghum, cabbage, and groundnut [1]. The pest has both migratory and localised dispersal habits with the ability to travel over $500 \mathrm{~km}$ aided by wind [2].

The FAW which was recently introduced into Africa is rapidly spreading throughout the tropical and subtropical regions of the continent, causing significant yield losses of maize [3]. Studies show that infestation rate of 5 larvae per plant can reduce yield by $6 \%$ in maize $[4,5]$. In its native range, the FAW moth travels to the north during fall and autumn and travels back to the tropical and subtropical regions during winter time. However, in Africa, where weather conditions and all year-round availability of host plant seem to favour FAW multiplication, it persists throughout the year. These conditions have made FAW the most important pest on maize in Africa.

Following this, many control measures have been developed to mitigate FAW damage on the African continent 
and elsewhere. These include host plant resistance, biological control, cultural practices, landscape management, and application of chemical pesticides [6]. Host plant resistance has been widely applied in this regard. For example, the three GEM (Germplasm Enhancement of Maize) inbred, derived from the incorporation of germplasm from Uruguay, Cuba, and Thailand, have shown source resistance to FAW in Southern USA [7]. Also, studies undertaken in USA and Brazil suggest that pyramiding multiple transgenes (in the same plant) is more effective in terms of FAW control and insect resistance management than single-gene-based resistance $[8,9]$. Crystal proteins isolated from Bacillus thuringiensis have been used to develop genetically modified FAW resistance maize, commonly called Bt maize, which is used only in South Africa in the entire African continent. These lethal proteins confer the FAW resistance in Bt maize [9-11].

Biologically, Braconid wasps and Campoletis flavicincta have been used as natural control agents against FAW populations [12-15]. This includes the use of entomopathogen at the microscopic level. Thus, a virus-based insecticide associated with the baculoviruses group has been used effectively to manage FAW [16-20]. Others have reported the use of entomopathogenic fungi [21-23], entomopathogenic nematodes [24-28], and bacteria [29-33].

Botanical pesticides are also another form of biological control agent which have been used against FAW over the years. Normally, they are used by smallholder farmers in Africa who lack the financial resources to buy improved seeds, pesticides, or other relatively expensive agricultural inputs [34-36]. Neem, chillies, lemon grass, and tobacco have been exploited for this purpose [37-39]. Aside from this, the use of low-cost agronomic practices and landscape management has been widely applied effectively as an integrated pest management strategy against FAW [40, 41]. These, like the botanical pesticides, are also important to smallholder farmers as far as FAW management is concerned. It is emphasised here that the most widely used control tool is synthetic insecticides, which until the introduction of FAW into Africa were not a major part of maize production systems of Africa.

In spite of these numerous approaches, the questions about affordability, environmental friendliness, and protection of insect diversity in the ecosystem as well as human health have been asked over the years. For instance, the use of genetically modified organisms (GMOs) has been strongly opposed in some African countries where stakeholders involved in the agricultural sector have raised genuine concerns about the application of products developed from the technology. Aside from this, the technology is very expensive to invest in and this will go a long way to affect prices of seeds, which smallholder farmers cannot afford. Similarly, the level of uncertainty in applying low-cost agronomic practices and botanical pesticide to control pest in Africa $[34,40,41]$ still persists. Thus, the efficacy of using these approaches to effectively control FAW is still in doubt, which means that the majority of these control measures need further scientific investigation before they can be approved for use by smallholder farmers. An exception to this is the push-pull approach applied on farmers' fields in East Africa [42]. Also, the technique of using other organisms to reduce the population of FAW is not commonly practiced on farmers' fields on the African continent, especially in subSaharan Africa, leaving many governments on the African continent with the choice of procuring and distributing synthetic pesticides to farmers for FAW control.

However, the challenge with the use of these synthetic pesticides is the lack of proper bioefficacy test under local agroecological conditions in Ghana and most African countries. Hence, this study tested the efficacy of Ampligo synthetic pesticide (a binary formulation with $100 \mathrm{~g}$ a.i./L chlorantraniliprole and $50 \mathrm{~g}$ a.i./L lambda-cyhalothrin) against FAW infestation on maize grown under irrigation in the coastal savannah agroecological zone of Ghana. The reason for conducting this study was to generate bioefficacy data for the product in Ghana, access the safety of the pesticide to maize and nontarget organism, and make recommendations for inclusion of Ampligo as one of the insecticides for FAW management.

\section{Materials and Methods}

2.1. Study Area Location and Description. The study was carried out at the Biotechnology and Nuclear Agriculture Research Institute (BNARI) of the Ghana Atomic Energy Commission (GAEC) research farm $\left(5^{\circ} 40^{\prime} 21^{\prime \prime} \mathrm{N}\right.$, $\left.0^{\circ} 13^{\prime} 00^{\prime \prime} \mathrm{W}\right)$, located in the Ga East Municipality of the Greater Accra Region of Ghana. The location of the trial field was selected based on previous history. The site had previously been cropped to maize without controlling fall armyworm (FAW) infestation.

2.2. Soil and Climate Characteristics of the Study Area. The soils of the study area belong to the savannah Ochrosols subgroup, which is characterised by very shallow, reddish brown, and brown concretionary, medium to light textured soil belying directly over sandstone, or quartzite or schists [43]. The physical and chemical properties of soils in the study area are described in the work of Frimpong et al. [44]. Rainfall of the study area is reported to be low and erratic. In fact, this informed our decision to grow maize crops under drip irrigation in the minor season of the coastal savannah environment. Previous rainfall data collected or recorded for the study area with the iMETOS ${ }^{\circledR}$ weather station, installed $50 \mathrm{~m}$ away from the study area, are documented in the works of Frimpong et al. [44] and Frimpong et al. [45].

The rainfall pattern in the coastal savannah agroecological environment is a bimodal type. Thus, two peaks of rainfall events occur in this environment, one in the major cropping season (beginning from May to July) and the second in the minor cropping season (beginning from September to November). The present rainfall amount recorded at the study area during the experimental trial showed highest rainfall in the months of May and October, respectively, for the major and minor cropping seasons (Table 1). In totality, $876.44 \mathrm{~mm}$ of rainfall was recorded for the major cropping season, while $369.89 \mathrm{~mm}$ was recorded 
for the minor cropping season. Averagely, for the year 2017, rainfall amount of $120.90 \mathrm{~mm} \pm 34.40$ was obtained for the study area. Apart from rainfall, other climatic elements were monitored. These were temperature, relative humidity, solar radiation, and wind speed. The average maximum and minimum temperatures recorded were $31.50^{\circ} \mathrm{C} \pm 0.60$ and $23.97^{\circ} \mathrm{C} \pm 0.22$, respectively. Maximum relative humidity and minimum relative humidity over the year 2017 averaged $99.84 \% \pm 0.11$ and $74.18 \% \pm 2.62$, respectively. The solar radiation and wind speed elements that gave information about how intense radiant energy coming from the sun and turbulent wind is in space were recorded monthly within the year, with the exception of January and February, probably for the reason of dysfunctionality of weather equipment. Averagely, $168.19 \mathrm{~W} / \mathrm{m}^{2} \pm 10.09$ radiation and $7.63 \mathrm{~m} /$ $\mathrm{s} \pm 0.37$ wind speed were recorded during the study period.

2.3. Field Preparation and Demarcation. The field was ploughed and harrowed. The field layout was transferred onto the harrowed land. The length of the field measured $32 \mathrm{~m}$ and the breadth measured $12.2 \mathrm{~m}$ to give an area of $390.40 \mathrm{~m}^{2}$. The field was divided into nine-unit experimental plots separated by paths with each unit plot measuring $10 \mathrm{~m}$ by $3 \mathrm{~m}\left(30 \mathrm{~m}^{2}\right)$. The paths between the unit plots measured $1.6 \mathrm{~m}$ along and $1.0 \mathrm{~m}$ across the entire field area.

2.4. Drip Irrigation Installation and Experimental Design. After demarcating the trial field, a family drip irrigation kit was spread onto the surface of the field. This covered the entire area of the field. The distance between lateral lines on the manifold (the main drip line that takes water from source) measured $60 \mathrm{~cm}$ and this numbered up to twentyone excluding paths. Along the laterals that convey water from the manifold to the field where plants are suited was the distance between emitters, which measured $60 \mathrm{~cm}$ excluding paths. The experimental design, which was a randomised complete block design, was plotted by using wooden pegs. As indicated earlier, unit experimental plots measuring $10 \mathrm{~m} \times 3 \mathrm{~m}$ were plotted nine times, together with paths, with measurements of $1.0 \mathrm{~m}$ and $1.6 \mathrm{~m}$ across and along field. The nine-unit plots plotted on the field were reached by multiplying the number of experimental treatments (three rates of Ampligo) and the number of times treatments were replicated (three replications) together. The drip system was tested for three days, morning and evening. This was done to ensure that all emitters on the laterals were functioning at the same rate; thus, water flow was at $1.1 \mathrm{~L} / \mathrm{hr}$. The delivery of water from the overhead tank of capacity $5000 \mathrm{~L}$ to the field was by gravity. The irrigation schedule was from September 25th, 2017, after seedling establishment to December 19th, 2017, when maize matured. This schedule was estimated based on actual evapotranspiration data determined for Mamaba maize variety grown at the same study area [45].

2.5. Source of Insecticide and Other Materials. The insecticide was Ampligo $150 \mathrm{ZC}$, a binary formulation with $100 \mathrm{~g}$ a.i./L chlorantraniliprole and $50 \mathrm{~g}$ a.i./L lambda-cyhalothrin. As a
ZC formulation, it is a combination of aqueous capsule suspension (CS) and aqueous suspension concentrate of technical material meant for dilution in water for final use. The Ampligo and Lumax ${ }^{\circledR}$ 537.5 SE herbicide were provided by Syngenta AG, Ghana. The NPK and Urea were procured from AGRIMAT, a registered agroinput dealer in Ghana. The Knapsack spraying machines (Matabi ${ }^{\circledR}$ Super Agro with a 16-litre capacity) used for insecticide and herbicide application were procured from RMG Ghana Limited. The maize used was a pioneer brand hybrid seed corn (no. 30Y87, moisture content $14 \%$ after $F_{1}$ generation) originating from Brazil. Seeds were treated from source against fungi, termites with Fludioxonil, Metalaxyl-M, and Thiamethoxam. The seeds used were procured from RMG Ghana Limited.

2.6. Seed Sowing and Germination. Seeds were sown on September 20th, 2017. Before sowing the seeds, the drip system was turned on for an hour to get the soil moist. After holes were created with the aid of a wooden dibber at a distance of $60 \mathrm{~cm}$ corresponding to that on the drip emitters on the laterals, each hole was seeded with one seed of the maize variety. The planting distance used was $60 \mathrm{~cm} \times 60 \mathrm{~cm}$. In each experimental unit, there were six lines with each line having approximately seventeen maize seeds multiplied by six giving approximately hundred seeded hills per unit plot. In totality, nine hundred seeds were sown on the entire field. Five days after seeding, seeds germinated into maize seedlings at a percentage germination of $90 \%$. On the fifth day, the $10 \%$ of seeds, which did not germinate, were replaced by filling up with new seeds.

2.7. Preparation of Ampligo Concentrations. There were three Ampligo concentrations of active ingredients for testing. These were $0 \mathrm{ml} / \mathrm{ha}$ (blank), $200 \mathrm{ml} / \mathrm{ha}$, and $240 \mathrm{ml} /$ ha. The concentrations given were diluted to the volume of water used in the Knapsack sprayer. For the $0 \mathrm{ml} / \mathrm{ha}$ rate, 3 litres (L) of water were measured into the Knapsack and sprayed on the three control experimental units as a blank. The $200 \mathrm{ml} / \mathrm{ha}$ rate of Ampligo was downscaled to the plot size of $90 \mathrm{~m}^{2}$ to give $1.8 \mathrm{ml}$ of Ampligo. The $1.8 \mathrm{ml}$ of Ampligo was measured into 3L of water, shaken, and stirred with a plunger for total dilution of the Ampligo active ingredients. Similarly, for the $240 \mathrm{ml} / \mathrm{ha}$ active ingredient, Ampligo rate was downscaled to $2.25 \mathrm{ml}$ of Ampligo per $90 \mathrm{~m}^{2}$ in $3 \mathrm{~L}$ of water.

2.8. Weed Control and Fertilizer Application. Lumax ${ }^{\circledR} 537.5$ $\mathrm{SE}$, a preemergence herbicide formulated specifically to control grasses and broad-leaved weeds in maize plantation, was used to control weeds on the field. The active ingredient is a mixture of $37.5 \mathrm{~g} / \mathrm{l}$ mesotrione $+375 \mathrm{~g} / \mathrm{l}$ $\mathrm{S}$-metolachlor $+125 \mathrm{~g} / \mathrm{l}$ terbuthylazine. This was applied to the entire study area after seed sowing, thus a week after ploughing and harrowing were done. The recommended application rate of $41 /$ ha was converted to active ingredient volume less than $41 /$ ha based on our experimental area. By 
TABle 1: Climatic records monitored and measured for the study area during the experimental trial.

\begin{tabular}{|c|c|c|c|c|c|c|c|c|}
\hline \multirow{2}{*}{ Month } & \multirow{2}{*}{ TMR } & \multicolumn{2}{|c|}{ Temperature } & \multicolumn{2}{|c|}{$\mathrm{RH}$} & \multirow{2}{*}{ Average $\mathrm{RH}$} & \multirow{2}{*}{ SR } & \multirow{2}{*}{ WS } \\
\hline & & Max. & Min. & Max. & Min. & & & \\
\hline January & 8.5 & - & - & - & - & - & - & - \\
\hline February & 118.5 & - & - & - & - & - & - & - \\
\hline March & 38.8 & 33.3 & 25.2 & 98.9 & 67.7 & 88.0 & 184.7 & 8.7 \\
\hline April & 46.5 & 32.8 & 24.9 & 99.5 & 70.5 & 88.2 & 204.7 & 8.3 \\
\hline May & 436.9 & 32.2 & 24.2 & 100.0 & 75.2 & 91.0 & 184.1 & 7.8 \\
\hline June & 211.9 & 30.4 & 24.0 & 100.0 & 80.7 & 93.7 & 147.2 & 7.0 \\
\hline July & 181.1 & 28.3 & 23.5 & 99.9 & 85.1 & 94.3 & 119.4 & 5.7 \\
\hline August & 38.8 & 28.3 & 22.9 & 100.0 & 82.8 & 93.4 & 119.4 & 5.8 \\
\hline September & 51.1 & 31.5 & 23.4 & 100.0 & 78.8 & 92.8 & 152.2 & 7.5 \\
\hline October & 169.4 & 32.2 & 24.2 & 100.0 & 72.1 & 90.5 & 204.6 & 9.1 \\
\hline November & 49.6 & 32.4 & 23.9 & 100.0 & 71.8 & 90.8 & 190.1 & 8.6 \\
\hline December & 99.8 & 33.6 & 23.5 & 100.0 & 57.1 & 85.8 & 175.5 & 7.9 \\
\hline
\end{tabular}

TMR is total monthly rainfall $(\mathrm{mm}), \mathrm{RH}$ is relative humidity $(\%), \mathrm{SR}$ is solar radiation $\left(\mathrm{W} / \mathrm{m}^{2}\right)$, and WS is wind speed $(\mathrm{m} / \mathrm{s})$. Em dash $(-)$ in the table indicates missing data.

this, $300 \mathrm{ml}$ active ingredient of the Lumax herbicide was measured into a $15 \mathrm{~L}$ capacity Knapsack sprayer for application. The control of weeds was done on September 22nd, 2017.

The previous soil physical and chemical properties history measured on soils in the study area [45] gave an indication that nutrient level was going to be a limiting factor to crop development apart from the FAW infestation detected on maize plantations in the area. Hence, fertilizer application rates were based (NPK and Urea applications at different growth stages) on the previous soil test analysis done for the study area. The rate of nutrient reserved in soil calculated based on the soil test result yielded $30 \mathrm{~kg} / \mathrm{ha}$, $429 \mathrm{~kg} / \mathrm{ha}$, and $97 \mathrm{~kg} / \mathrm{ha}$ for Phosphorus (P), Potassium (K), and Nitrogen $(\mathrm{N})$, respectively. The amounts of fertilizer required based on the $\% \mathrm{NPK}$ analysis (15\%) by soil were $5 \mathrm{~kg}$ $\mathrm{P} / \mathrm{ha}, 64 \mathrm{~kg} \mathrm{~K} / \mathrm{ha}$, and $15 \mathrm{~kg} \mathrm{~N} / \mathrm{ha}$. In totality, the amounts of NPK fertilizer weighed for application were $144 \mathrm{~g}$ P, $1843 \mathrm{~g}$ $\mathrm{K}$, and $432 \mathrm{~g} \mathrm{~N}$, to give $2419 \mathrm{~g} \mathrm{NPK}$ fertilizer for an area of $288 \mathrm{~m}^{2}$ (adjusted from $390.4 \mathrm{~m}^{2}$ to $288 \mathrm{~m}^{2}$ ). This area contained 900 maize plants, sown at one seed per hill. Therefore, 1 young maize plant received $3 \mathrm{~g}$ NPK fertilizer two weeks after germination, thus on October 9th, 2017. The NPK fertilizer was side-placed after watering maize plants uniformly for 3 hours. Urea was the second fertilizer applied after the NPK fertilizer. Following the same procedure, the $97 \mathrm{~kg} / \mathrm{ha}$ of $\mathrm{N}$ in soil was converted to rate of Urea application based on the $46 \%$ nitrogen content in Urea. This yielded a rate of $45 \mathrm{kgN} / \mathrm{ha}$. So, $1285.06 \mathrm{~g}$ Urea was weighed for application to 900 maize plants on an area of $288 \mathrm{~m}^{2}$. By this, each experimental unit received $142.78 \mathrm{~g}$ Urea. This activity happened on November 2nd, 2017.

2.9. Ampligo Application and Fall Armyworm Sampling. After preparing the Ampligo concentrations, it was applied to maize crops immediately after FAW was detected on plants based on daily sampling, starting seven days after germination. The first treatment application was on October 4th, 2017, and this was immediately followed by the second application, which happened on October 11th, 2017. The $1.8 \mathrm{ml}$ active ingredient of Ampligo diluted in $3 \mathrm{~L}$ of water contained in the Knapsack sprayer was sprayed on three experimental units labelled AMPLIGO_1 in the direction of the wind speed that prevailed during the trial. The nozzle of the spraying gun was adjusted to avoid drift of the chemical. In the same way, the $2.25 \mathrm{ml}$ active ingredient of Ampligo was applied to maize crops on three experimental units labelled AMPLIGO_2. During spraying, care was taken to direct the insecticide into the whorl of the maize plants. Sampling for FAW had already begun 7 days after germination before Ampligo application. Sampling for FAW continued after Ampligo application. Ten maize plants were tagged in the middle row and this covered an area of $4.32 \mathrm{~m}^{2}$. Randomly, FAW were sampled every 7 days early in the morning up to the 63rd day. To explain, the first application of Ampligo and initial data on FAW infestation level as well as damage grading on leaf were carried out when FAW infestation was noticed as indicated before. The second sampling of FAW, damage grading, and phytotoxicity scoring were carried out 7 days after the first Ampligo application. This continued after applying the second Ampligo schedule. Since then, data were collected on weekly basis at the vegetative, reproductive, and maturity stages of the maize plant.

2.9.1. Measured Parameters. Fall armyworm larvae, egg batches, and other nontarget organisms' numbers were determined by counting from the ten selected and tagged maize in the two middle rows of each plot. This was done randomly at seven days' intervals, thus before and after Ampligo application to maize on plots against FAW larvae infestation. Also, FAW larvae were counted in cob and tassel during the reproductive stage as a measure of cob and tassel damage. These were scored as "A" and "P." Thus, cob and tassel damage was scored as " $P$ " if there were FAW larvae present and "A" if there were no FAW larvae (absent). The damage rating of maize leaf as maize advances in age was determined on a scale of 1-9. Also, this was done before and after Ampligo application to maize on plots. The meaning and how to assign the grades of 1-9 to maize leaf infested by FAW are documented in the work of Davis et al. [46]. Fall 
armyworm density was determined based on the average fall armyworm numbers sampled per maize. The maize grain yield was measured at two stages of development. Thus, the first measured as fresh grain on the cob, two weeks before maturity, and the second as dry grain deshelled from the dry cob at maturity, which was 90 days. The fresh yield was measured from four sampled maize from an area of $0.72 \mathrm{~m}^{2}$. Fresh ears per plot were removed by hand, weighed, and recorded. Based on the area sampled, the weights denoting yield of fresh maize were expressed in kilogram per hectare. On the other hand, dry grain yield was determined from fifteen samples of maize taken from the two middle rows per plot. The area sampled was $10.8 \mathrm{~m}^{2}$. Ears were removed from each fifteen samples per plot, labelled, and dehusked. The dehusked samples were dried for 14 days and after dry grains on cobs were removed for weighing. After getting the weights per plot, a formula described in the work of Lauer [47] was used to determine the dry grain yield at $15.5 \%$ moisture content.

2.9.2. Diversity of Nontarget Organisms. Diversity of nontarget organisms on the different experimental units was determined by counting any nontarget organism on each maize sample. SIMPSON's index (equation (1)) was used to estimate the impact of Ampligo on nontarget organisms' diversity (equation (2)) in the insect ecosystem found in the coastal savannah agroecological zone [48]. This index is written as

$$
D=\frac{\sum n_{i\left(n_{i}-1\right)}}{N(N-1)}
$$

where $D$ is SIMPSON'S index, $N$ is the total number of individuals, and $n$ is the total number of particular individuals.

$$
\text { SIMPSON's index of diversity }=1-D \text {. }
$$

2.9.3. Data Analysis. The total number of FAW larvae counted on the maize was plotted against the sampling days in Microsoft excel for trend analysis over the period of the experiment. F-test (analysis of variance, ANOVA) was performed for data collected on total number of FAW larvae sampled from the field. Data on the total number of FAW larvae, number of egg batches, damage ratings of leaf, and maize grain yield were analysed using one-way ANOVA described in the Genstat statistical software, 12th edition. Means obtained after the ANOVA were represented in Microsoft excel using column graph display. The least significant difference (LSD) test at a probability level of $5 \%$ was used to separate means, thus when the F-test proved significant. Also, correlation and regression analysis were performed between the FAW numbers and the damage ratings and Ampligo application rates used during the experiment.

\section{Results}

3.1. FAW Number, Number of Egg Batches, and FAW Density against Sampling Days. There was a general decline in the average number of fall armyworms (FAW) for all three treatments evaluated during the trial. Thus, the number of FAW sampled over the period was on the rise from the initial population on the first day of sampling and began showing a decrease in number 14 days after first Ampligo application (Figure 1(a)). This decline in FAW continued after the second application, which saw the larvae decreasing to zero at 28 days and rising marginally at 35 days. Constantly, the FAW numbers became insignificant on the treated maize plots after 35 to 56 days. However, the numbers rose again after 56 days (Figure 1(a)). The average egg batches collected over the sampling period declined with time. The initial eggs collected were found to be highest on maize plots treated with $240 \mathrm{ml} / \mathrm{ha}$, followed by the control and $200 \mathrm{ml} / \mathrm{ha}$ at 14 days after germination. The rate of decline in egg batches was observed to be greater on maize treated with $240 \mathrm{ml} / \mathrm{ha}$ rate of Ampligo. Thus, the reduction in the eggs declined from 14 to 28 days and remained low as the treated maize advanced in age (Figure 1(b)). A similar trend was observed on plots treated with Ampligo at $200 \mathrm{ml} / \mathrm{ha}$, where the decrease in eggs sampled happened from 14 to 35 days, with no sign of further egg batch samples over the sampling period. On the control plots, the general decline in egg batches was seen but this decreased up to 28 days, appreciated at 35 days, and dropped at 42 days onwards (Figure 1(b)).

A one-way analysis of variance was performed on data set plotted in Figures 1(a) and 1(b) to ascertain whether differences existed among averages determined for total FAW and egg batches numbers determined during the trial. Similarly, for the same reason it was done for average damage ratings determined over the sampling days (Table 2). Initially, the $F$-test performed showed no significant differences $(p>0.05)$ among total FAW determined under the three treatments for the first fourteen days. However, for the subsequent days (specifically, 21 and 28), it emerged that statistical significance $(p<0.05)$ existed among total FAW counted under $0 \mathrm{ml} / \mathrm{ha}, 200 \mathrm{ml} / \mathrm{ha}$, and $240 \mathrm{ml} / \mathrm{ha}$ Ampligo rates (Table 2). Beyond 35 days of sampling, no differences were found among the total FAW determined just like the number of egg batches found on maize leaves and whorls. For the damage rating of maize leaves, there was a statistical significance $(p<0.05)$ from day 21 to day 49.

The total FAW numbers counted on both treated and untreated maize growing on the field were converted to FAW density. The density was at peak during the first 14 days after emergence of maize. However, this was not significantly different, that is, for both densities expressed in units of larvae/maize (Table 3). The significance rather existed at 21 days after germination. From 28 to 63 days after germination, FAW density declined to almost undetectable levels, especially on the treated plots. Infestation was observed to be very critical during the first three weeks after germination.

\subsection{FAW Number and Damage Rating of Leaf.} Correlating the number of FAW to damage rating of leaf gave a strong positive relationship (Figure 2(a)). From Figure 2(a), maize that were not treated showed high damaging effects as the FAW number increased. The correlation was very significant at $p=0.018$. Although FAW 


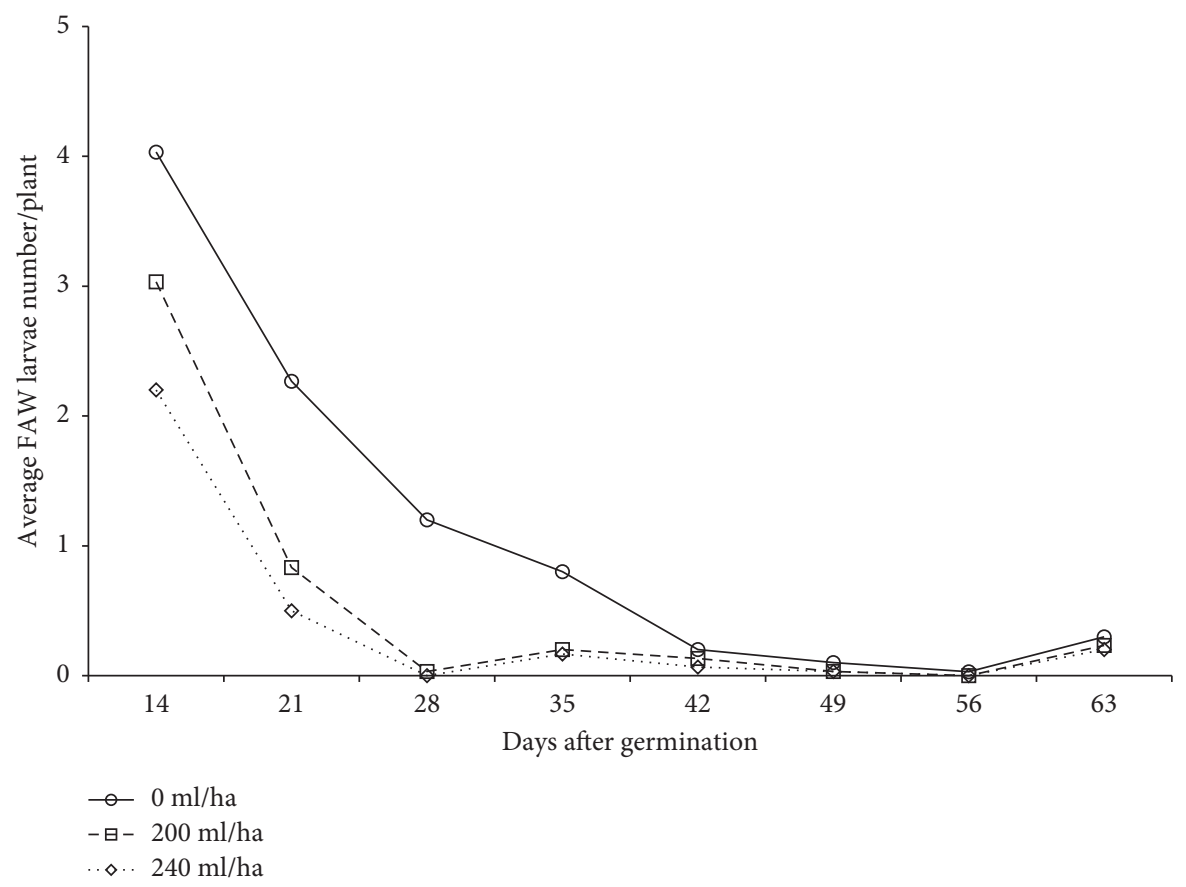

(a)

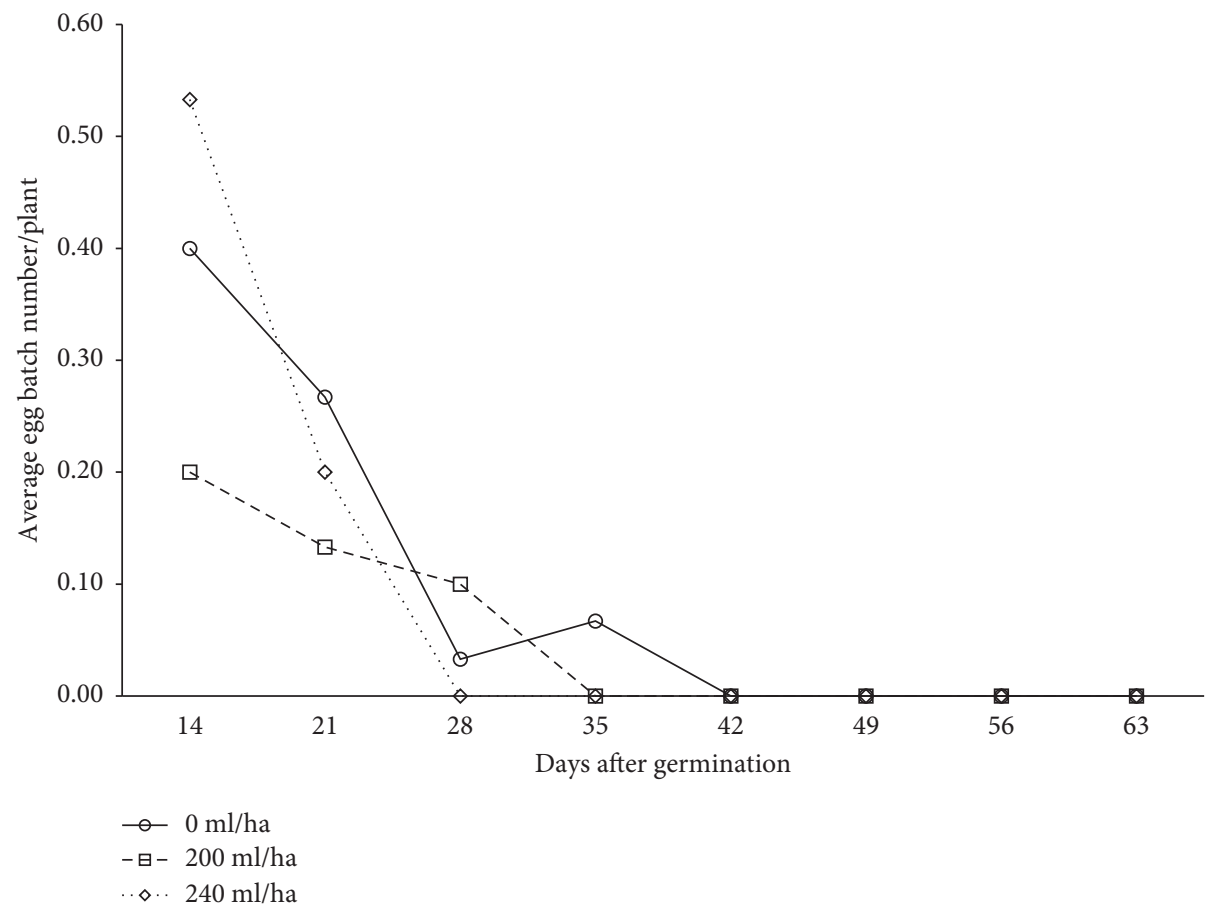

(b)

Figure 1: A graph showing (a) fall armyworm larvae and (b) egg batches number counted on maize leaf and whorl during the sampling days for Ampligo applied at rates of $0 \mathrm{ml} / \mathrm{ha}, 200 \mathrm{ml} / \mathrm{ha}$, and $240 \mathrm{ml} / \mathrm{ha}$.

were found on the treated plots, they did not cause damage like that seen on the untreated plots. This could probably be due to the fact that FAW became inactive after Ampligo application. This is evident in the significant correlation of FAW numbers and damage rating of leaf obtained for treated maize; $p=0.030$ and $p=0.002$ for Ampligo at rates of $200 \mathrm{ml} / \mathrm{ha}$ and $240 \mathrm{ml} / \mathrm{ha}$, respectively (Figure 2(a)).
3.3. FAW Density and Ampligo Application Rates. There was a negative correlation for the relation between FAW density and rates of Ampligo used during the trial. This specifically was observed for data collected at 14 and 21 days (Figure 2(b)). However, as the maize plants advanced in age, the FAW density declined irrespective of treatment. The initial correlation between FAW density and Ampligo 
TABLE 2: Total numbers of fall armyworms and egg batches and damage ratings of maize leaf treated with Ampligo at rates of $0 \mathrm{ml} / \mathrm{ha}$, $200 \mathrm{ml} / \mathrm{ha}$, and $240 \mathrm{ml} / \mathrm{ha}$.

\begin{tabular}{|c|c|c|c|c|c|c|c|c|c|c|c|c|}
\hline \multirow{2}{*}{$\mathrm{D}$} & \multicolumn{4}{|c|}{ Total number of fall armyworms } & \multicolumn{4}{|c|}{ Total number of egg batches } & \multicolumn{4}{|c|}{ Damage ratings on leaf } \\
\hline & $0 \mathrm{ml} / \mathrm{ha}$ & $200 \mathrm{ml} / \mathrm{ha}$ & $240 \mathrm{ml} / \mathrm{ha}$ & $p$ values & $0 \mathrm{ml} / \mathrm{ha}$ & $200 \mathrm{ml} / \mathrm{ha}$ & $240 \mathrm{ml} / \mathrm{ha}$ & $p$ values & $0 \mathrm{ml} / \mathrm{ha}$ & $200 \mathrm{ml} / \mathrm{ha}$ & $240 \mathrm{ml} / \mathrm{ha}$ & $p$ values \\
\hline 14 & 40 & 30 & 22 & $0.455^{\mathrm{ns}}$ & 4 & 2 & 5 & $0.525^{\mathrm{ns}}$ & 3 & 3 & 3 & $0.476^{\mathrm{ns}}$ \\
\hline 21 & $23^{\mathrm{a}}$ & $8^{\mathrm{b}}$ & $3^{\mathrm{b}}$ & $0.005^{* * *}$ & 3 & 1 & 1 & $0.499^{\text {ns }}$ & $5^{\mathrm{a}}$ & $1^{\mathrm{b}}$ & $1^{\mathrm{b}}$ & $0.002^{* * *}$ \\
\hline 28 & $12^{\mathrm{a}}$ & $0^{\mathrm{b}}$ & $0^{\mathrm{b}}$ & $<0.001^{* * *}$ & 1 & 0 & 0 & $0.174^{\mathrm{ns}}$ & $4^{\mathrm{a}}$ & $0^{\mathrm{b}}$ & $0^{\mathrm{b}}$ & $<0.001^{* * *}$ \\
\hline 35 & 8 & 2 & 2 & $0.052^{\mathrm{ns}}$ & 1 & 0 & 0 & $0.444^{\mathrm{ns}}$ & $5^{\mathrm{a}}$ & $1^{\mathrm{b}}$ & $0^{\mathrm{b}}$ & $<0.001^{* * *}$ \\
\hline 42 & 2 & 1 & 1 & $0.646^{\mathrm{ns}}$ & 0 & 0 & 0 & - & $4^{\mathrm{a}}$ & $2^{\mathrm{b}}$ & $1^{\mathrm{b}}$ & $0.001^{* * *}$ \\
\hline 49 & 1 & 0 & 0 & $0.538^{\mathrm{ns}}$ & 0 & 0 & 0 & - & $3^{\mathrm{a}}$ & $1^{\mathrm{b}}$ & $1^{\mathrm{b}}$ & $0.014^{* *}$ \\
\hline 56 & 0 & 0 & 0 & $0.444^{\mathrm{ns}}$ & 0 & 0 & 0 & - & 2 & 1 & 1 & $0.108^{\mathrm{ns}}$ \\
\hline 63 & 3 & 2 & 2 & $0.875^{\mathrm{ns}}$ & 0 & 0 & 0 & - & 2 & 0 & 0 & $0.101^{\mathrm{ns}}$ \\
\hline
\end{tabular}

$\mathrm{D}$ is days after germination. One way-analysis of variance and mean separation by the least significant difference test at significance level of $5 \%$. Means followed by same letters are not significantly different but those with different letters show significant differences. ns indicates no significance. The double and triple asterisks indicate high and extreme significance.

TABLE 3: Fall armyworm (FAW) density on maize leaf and whorl before and after Ampligo application.

\begin{tabular}{|c|c|c|c|c|}
\hline \multirow{2}{*}{ Days } & \multicolumn{3}{|c|}{ FAW density (larvae/maize) } & \multirow{2}{*}{$p$ values } \\
\hline & $0 \mathrm{ml} / \mathrm{ha}$ & $200 \mathrm{ml} / \mathrm{ha}$ & $240 \mathrm{ml} / \mathrm{ha}$ & \\
\hline 14 & $3.73^{\mathrm{a}}$ & $2.81^{\mathrm{a}}$ & $2.04^{\mathrm{a}}$ & $0.181^{\mathrm{ns}}$ \\
\hline 21 & $2.10^{\mathrm{a}}$ & $0.77^{\mathrm{b}}$ & $0.46^{\mathrm{b}}$ & $0.005^{* * *}$ \\
\hline 28 & 0 & 0 & 0 & - \\
\hline 35 & 0 & 0 & 0 & - \\
\hline 42 & 0 & 0 & 0 & - \\
\hline 49 & 0 & 0 & 0 & - \\
\hline 56 & 0 & 0 & 0 & - \\
\hline 63 & 0 & 0 & 0 & - \\
\hline
\end{tabular}

application rates was not significantly different at 5\% probability level. Between 14 and 21 days after which the first and second applications have been administered, the correlation between the FAW density and Ampligo applications rates emerged significantly $(p=0.014)$ at 21 days. Beyond 21 days of maize growth, subsequent correlations never emerged.

3.4. Ampligo Application and Nontarget Organism. A total of 635 nontarget arthropods belonging to 13 general groupings were collected from the three treated plots. The control plots contributed $54 \%$ of these nontarget organisms, while plots treated with Ampligo at rates of $200 \mathrm{ml} / \mathrm{ha}$ and $240 \mathrm{ml} / \mathrm{ha}$ contributed $22 \%$ and $24 \%$, respectively. The nontarget organisms collected include beneficial insects, which were predatory in nature (Table 4). It is important to note that no stem borers or other lepidopteran pests were collected on control plots, with none recorded on both Ampligo treated plots. Also, SIMPSON's index of diversity estimated for nontarget organisms found on the experimental plots was 0.602 .

3.5. FAW Infestation, Phytotoxicity Level, and Grain Yield. The phytotoxicity factors monitored on both treated and untreated maize plants were found to be low over the sampling days (Table 5). Damage due to FAW infestation was more visible on the leaf than the phytotoxicity symptoms, which never emerged. In fact, they all scored below 1 on the phytotoxicity scale used for the assessment (Table 5).
Also, FAW data on cob and tassel were monitored from 49 to 63 days on a weekly basis. The information gathered showed that there was some level of damage at the reproductive stage. The FAW damage to tassel and cob in the control plots was estimated to be $5 \%$ for both. Similarly, FAW damage to tassel and cob of maize treated with Ampligo at $200 \mathrm{ml} / \mathrm{ha}$ rate was estimated as 3.30 and $0 \%$, respectively, while maize treated with Ampligo at a rate of $240 \mathrm{ml} / \mathrm{ha}$ had $0 \% \mathrm{FAW}$ damage on both tassel and cob.

FAW sampling ended on the 63rd day of maize growth, just when the maize had advanced into reproductive phase. The reason was that records taken beyond 21 days showed a near absence of the pest. Linking this to maize yield determined at maturity, statistical significance was not observed among yield determined from both the control and treated maize plots. The FAW infestation, thus, had no effect on maize grain on the fresh cob and dry grain yield deshelled from the dry cob as well (Figures 3(a) and 3(b)).

\section{Discussion}

4.1. Maize Growth Stages and Fall Armyworm Attack. Fall armyworm (FAW) attack in maize and other crops such as sorghum and cotton was reported in several studies conducted ever since the pest emerged in the Americas and their surrounding nations [8]. These studies focused on how pesticides should be used as a means to manage the infestation of FAW at different growth stages during crop development. These growth stages of maize become important for sampling and making recommendations on an action 


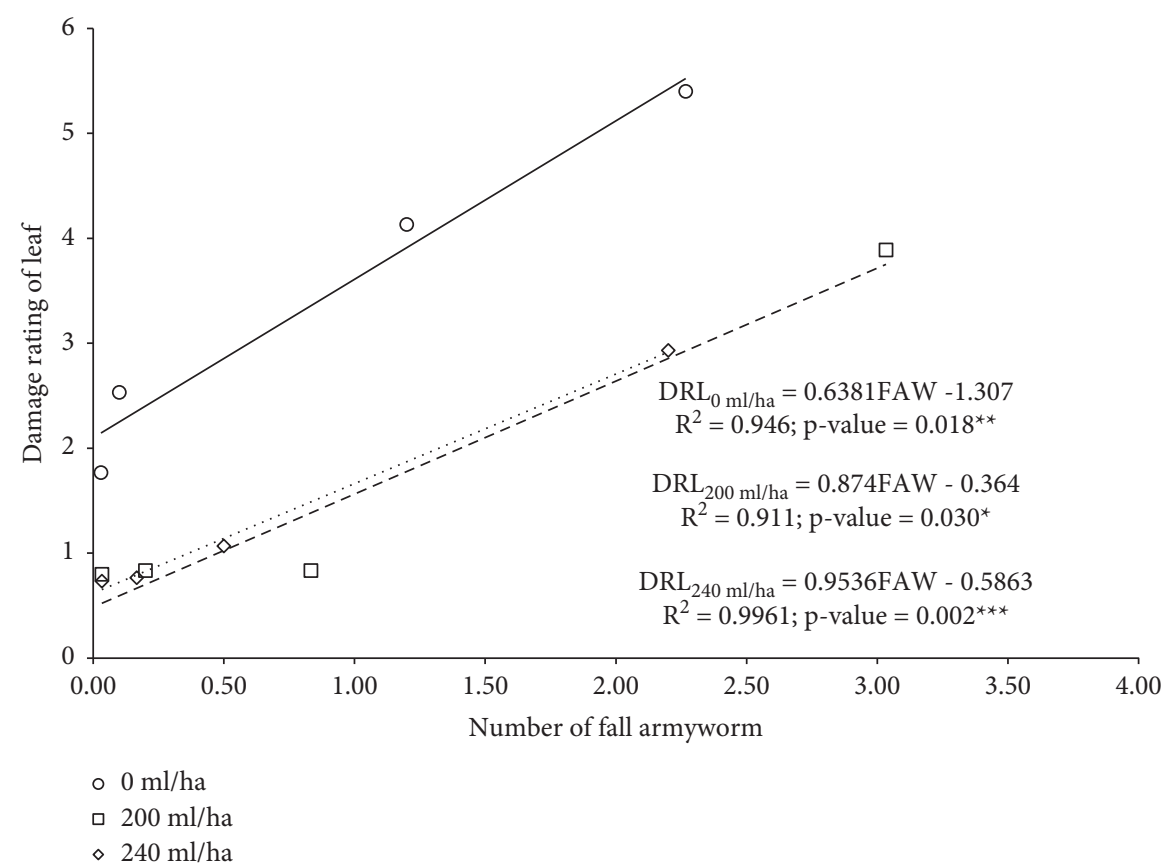

(a)

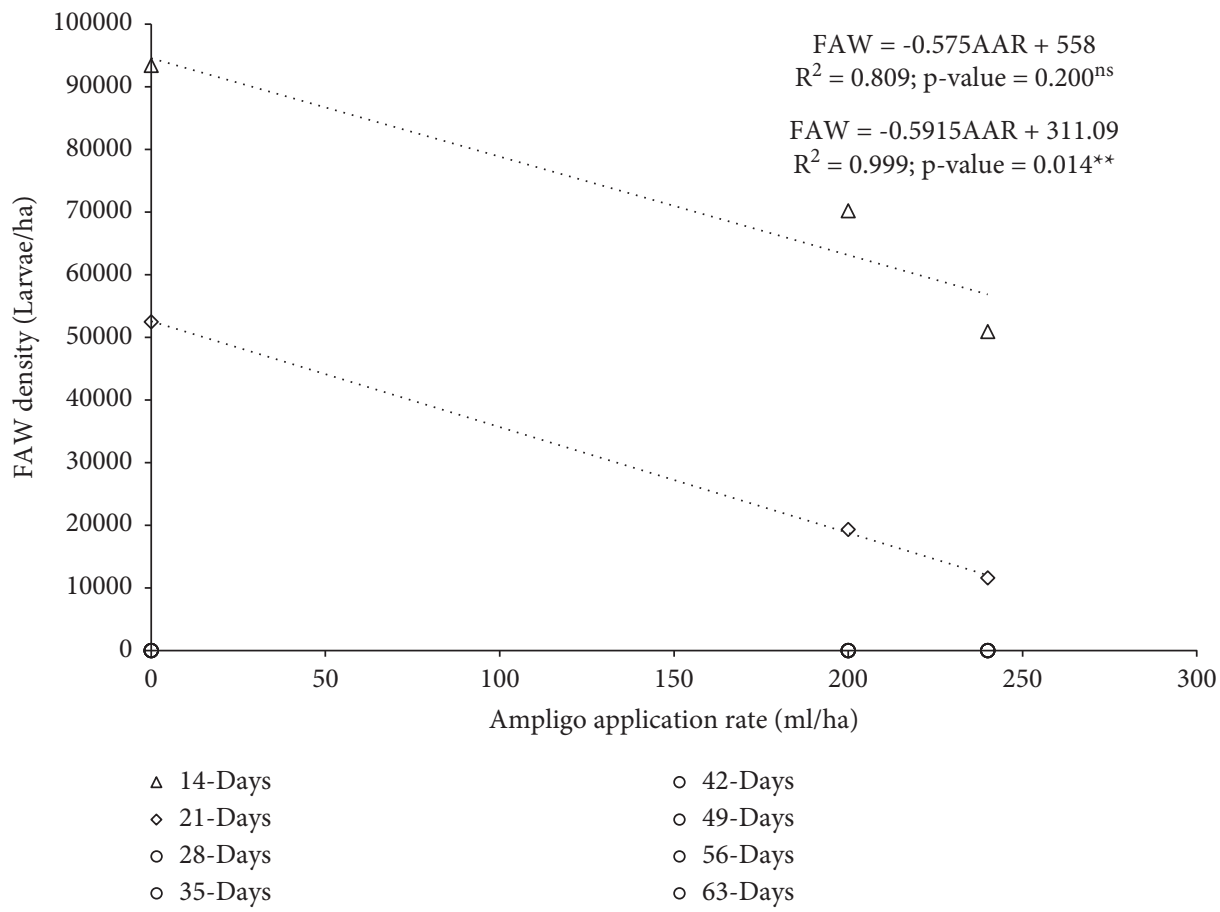

(b)

Figure 2: Relationship between fall armyworm density and (a) damage rating of leaf and (b) Ampligo application rates used for controlling armyworm infestation on maize at different growth stages.

threshold for a particular pesticide for FAW control in a specific agroecosystem. It is reported in other jurisdictions that FAW not only cause defoliation during the stage but also can cause direct injury to the tassel and ear making control most critical at the early vegetative stage $[49,50]$.

This study investigated the efficacy of Ampligo pesticide against the infestation of FAW attack from the early whorl to reproductive stage of maize grown under drip irrigation conditions in the coastal savannah agroecological zone of Ghana. Upon application of these treatments, we observed a general decline in the numbers of FAW, egg batches, and larvae on sampled maize plants. Conversely, the numbers were high at the early whorl stage, thus in the first 14 days after emergence for both larvae and egg batches. The obvious 
TABLE 4: Abundance of nontarget insects collected on maize during the sampling period.

\begin{tabular}{lccc}
\hline \multicolumn{4}{c}{ Ampligo treatments } \\
Fauna & $0 \mathrm{ml} / \mathrm{ha}$ & $200 \mathrm{ml} / \mathrm{ha}$ & $240 \mathrm{ml} / \mathrm{ha}$ \\
\hline Ant & 222 & 63 & 87 \\
Cocoon & 1 & 1 & 0 \\
Cotton jassid & 1 & 0 & 1 \\
Grasshopper & 1 & 1 & 1 \\
Ladybird beetle & 0 & 0 & 3 \\
Leaf beetle & 0 & 1 & 0 \\
Moth & 0 & 1 & 0 \\
Plant bug & 0 & 3 & 3 \\
Plant hopper & 18 & 25 & 20 \\
Praying mantid & 1 & 0 & 0 \\
Spider & 56 & 33 & 23 \\
Stem borer & 4 & 0 & 0 \\
Weevil & 22 & 5 & 3 \\
Whitefly & 19 & 8 & 9 \\
Total & 344 & 141 & 150 \\
\hline
\end{tabular}

SIMPSON's index of diversity $=0.602$.

TABle 5: The effect of Ampligo treatments on the phytotoxic factors considered during sampling for FAW maize leaf and whorl.

\begin{tabular}{lccc}
\hline \multirow{2}{*}{ Phytotoxic factors } & \multicolumn{3}{c}{ Ampligo treatments } \\
& $0 \mathrm{ml} / \mathrm{ha}$ & $200 \mathrm{ml} / \mathrm{ha}$ & $240 \mathrm{ml} / \mathrm{ha}$ \\
\hline Thinning & $0.1 \pm 0.04$ & $0.004 \pm 0.004$ & $0.00 \pm 0.00$ \\
Chlorosis & $0.4 \pm 0.05$ & $0.05 \pm 0.018$ & $0.04 \pm 0.01$ \\
Necrosis & $0.5 \pm 0.06$ & $0.1 \pm 0.03$ & $0.1 \pm 0.03$ \\
Wilting & $0.3 \pm 0.05$ & $0.02 \pm 0.01$ & $0.00 \pm 0.00$ \\
Rolling & $0.2 \pm 0.04$ & $0.01 \pm 0.007$ & $0.005 \pm 0.005$ \\
Curling & $0.4 \pm 0.05$ & $0.03 \pm 0.01$ & $0.01 \pm 0.008$ \\
Stunting & $0.6 \pm 0.07$ & $0.1 \pm 0.03$ & $0.06 \pm 0.02$ \\
\hline
\end{tabular}

Phytotoxicity scale: $0.0-1.0=$ low phytotoxicity; $1.0-2.0=$ medium phytotoxicity; 2.0-3.0 = high phytotoxicity; scale modified from EPPO (2014).

reason is that maize on the field were not treated up to the first 14 days after emergence, including the control plots, hence the high numbers of FAW and egg batches. However, after applying the concentrations of the Ampligo treatments, except the control plots, there was a decline in the pest larvae and eggs, indicating the effectiveness of Ampligo rates, $200 \mathrm{ml} / \mathrm{ha}$ and $240 \mathrm{ml} / \mathrm{ha}$, against FAW at the early whorl stage of maize growth. Also, this means that treated maize that were on the field were free from FAW attack at the early whorl stage and this allowed complete development of leaves without perforations, which could have reduced photosynthetic efficiency of maize leaves.

Comparatively, the untreated maize on the other hand showed a decline in the numbers of both larvae and eggs as maize advanced in age. However, the declining rate was slower compared to maize on the treated plots, which showed massive reduction rates in FAW and eggs for Ampligo at $200 \mathrm{ml} / \mathrm{ha}$ and $240 \mathrm{ml} / \mathrm{h}$. The rate of reduction in both FAW and eggs on the control maize plots reduced to the barest minimum at day 49 (where maize was still actively growing in terms of new leaves development and tassel formation). This reduction could be due to probably the presence of insect natural enemies of the FAW, which authenticates the work of Meagher et al. [14], which investigated the use of Braconid wasps and Campoletis flavicincta as natural enemies against FAW and egg infestation.

\subsection{Ampligo Effect on Fall Armyworm Population.} Generally, Ampligo application rates at $200 \mathrm{ml} / \mathrm{ha}$ and $240 \mathrm{ml} / \mathrm{ha}$ as provided by the suppliers for bioefficacy test had significant $(p<0.05)$ effect on the FAW larval density but not on eggs batch density. However, as maize advanced in age, a very significant decrease in total FAW and damage rating of leaf was seen at 21 and 28 days on the treated maize plots. The pest was very active at the early vegetative stage of maize growth as indicated in a similar work done by Young [51]. Maize at the early stage was very succulent and juicy with low lignin content in leaf, hence the ability of FAW to cause more damage to leaves especially on the control maize plots. Beyond the 28th day, the control plots showed a decline in FAW but still the damage rating on the leaf remained at significant score values of 4, 5, and even 6 from 35 to 49 days, indicating that the damage caused by the FAW on the controlled maize plots was more severe at the early whorl stage compared to the treated maize, which showed low damage rating scores.

After the critical times, where FAW showed its activeness in destroying the maize especially on the control plots, statistical significance, which denotes the effect of the chemical, was not seen among the subsequent FAW and eggs sampled on both treated and nontreated plots. This probably could be attributed to the systemic nature of Ampligo, which got most of the FAW off the maize at the advanced stage, hence the dwindling effect. Supporting this are studies that have also tested the efficacy of Spinosad against beet armyworm infestations elsewhere, with excellent control achievement [52]. However, the numbers of FAW larvae on the control maize decreased more slowly compared to the treated maize. The reduction could therefore be due to the abundant natural enemies recorded on the control plots.

The damage by FAW was scored on a visual rating scale of 0 to 9 with 0 being no visible leaf damage and 9 being conditions where the whorl and furl leaves are almost totally damaged [46]. To understand this aspect of the information gathered in relation to the effectiveness of Ampligo, the correlation and regression technique was applied. Correlating the number of FAW to damage rating on leaf showed a strong positive relationship. Hence, the number of FAW increased as the degree of damage caused by the FAW also increased. We, therefore, inferred from Figure 2(a) that untreated maize were more highly damaged as the FAW number increased with damage rating increasing from 2 (minimal visible leaf damage) to 6 (marginal leaf damage). However, for maize treated with Ampligo at rates of $200 \mathrm{ml} /$ ha and $240 \mathrm{ml} / \mathrm{ha}$, the damage rating on leaf was at the minimal visible leaf damage level $(<4)$.

The total FAW number was converted to FAW density in relation to the area sampled during the maize growing period. Thus, the FAW numbers sampled on both treated and nontreated maize plots were converted to simple terms of larvae/ha and larvae/maize. The essence was to find out 


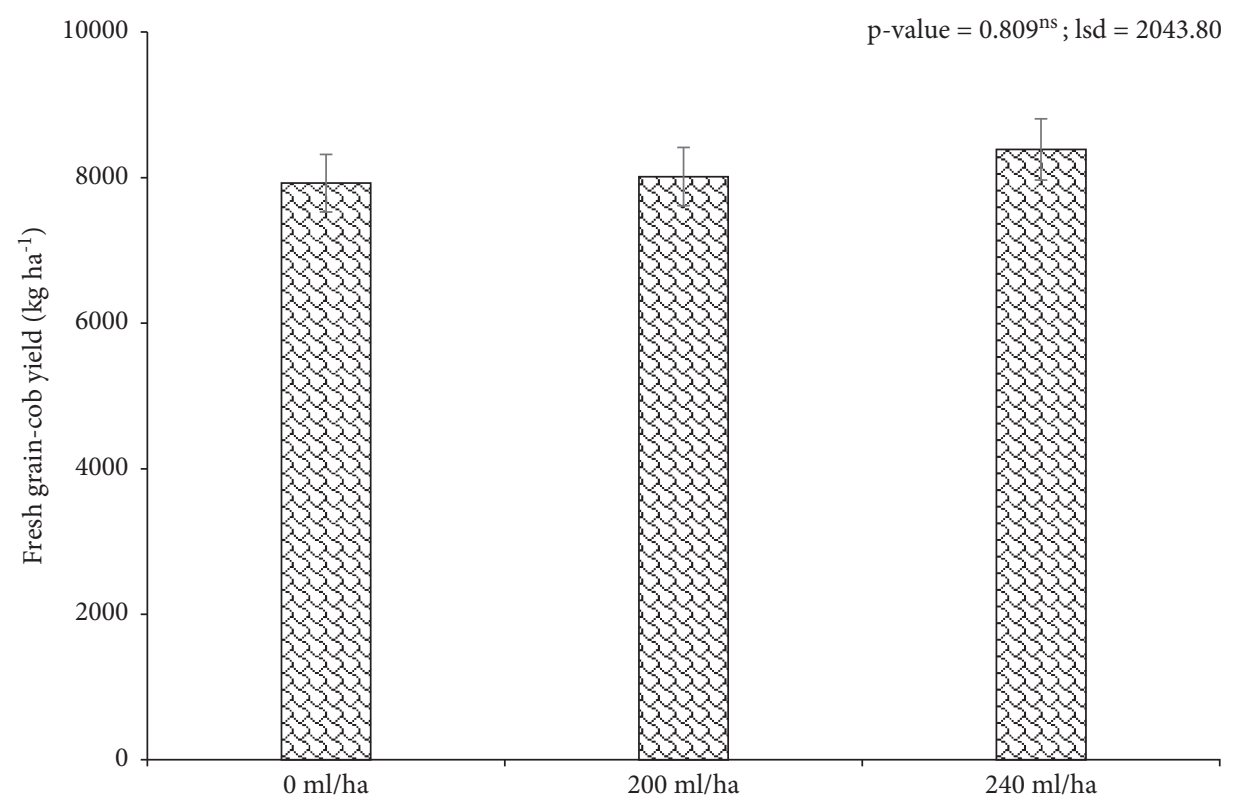

(a)

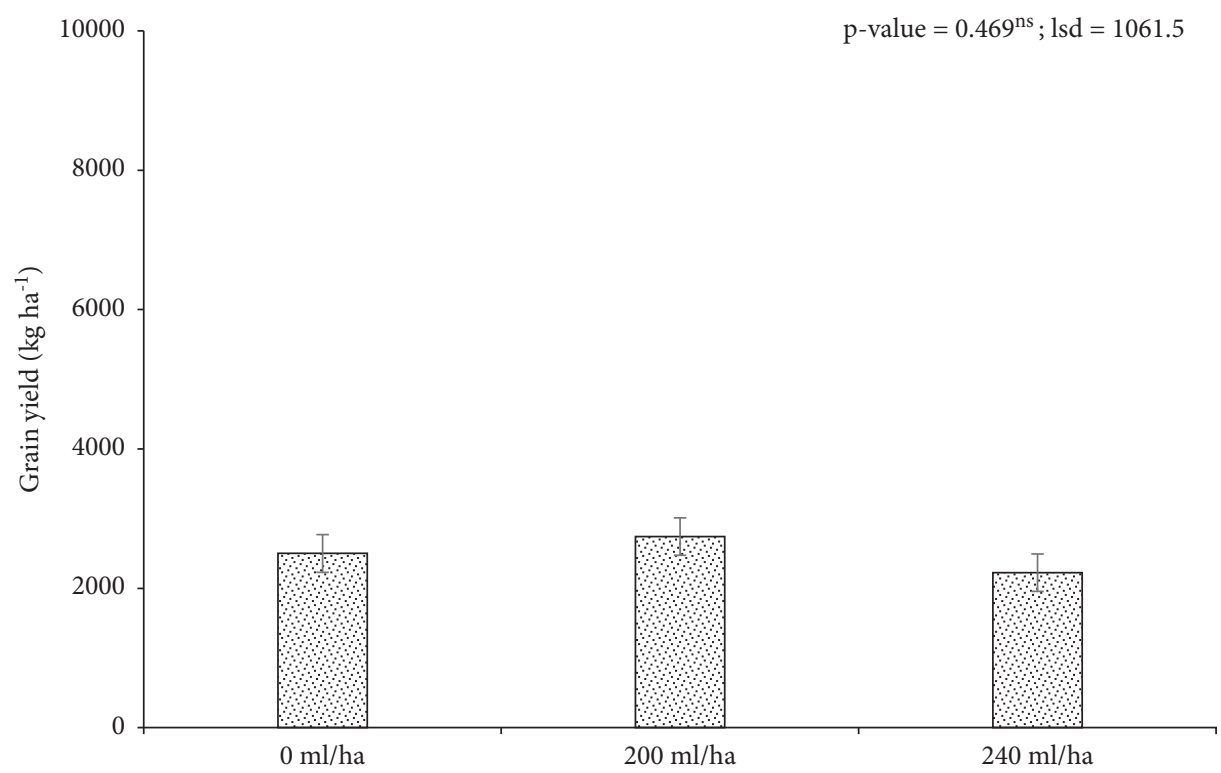

(b)

FIGURE 3: Maize grain yield determined as (a) fresh grain on cob after 70 days of growth and (b) dry grain deshelled from cob at maturity.

whether FAW density responds directly to the rates of Ampligo used for the trial. Upon correlating, we found that the relationship was not direct as expected but rather indirectly proportional, indicating that as the rate of Ampligo application increased the density of FAW decreased over the maize growing period. On the other hand, the FAW densities were found not to be significantly different $(p>0.05)$ at first 14 days after germination but became significant from 7 days after first application. This was similar to the result of Cook et al. [53], who showed beet armyworm larval densities in Thiodicarb treated plots not to be significantly different from those in the nontreated plots after 7 days. This early Ampligo application might have been responsible for the massive differences in FAW densities on treated maize plots as compared to the nontreated. Similarly, several pesticides treatments have been reported to significantly reduce beet armyworm densities in situations where those observed in nontreated plots were compared to treated plots [54].

Considering figures recorded under treatments with $200 \mathrm{ml} /$ ha and $240 \mathrm{ml} /$ ha in Table 3, the drop in FAW density accounted for $56.90 \%$ and $62.96 \%$, respectively, of the total FAW seen on the treated plots, indicating that Ampligo significantly suppressed the FAW density on the treated plots. Our findings shared similar characteristics of chemical effectiveness with some pesticides such as Thiamethoxam plus lambda-cyhalothrin applied as foliar treatment 8 days 
after plant emergence and achieving $86 \%$ pest control 7 days after spraying [55]. In the same studies, Lufenuron applied at 12 DAE when leaves were scrapped and perforated by FAW larvae provided $75 \%$ pest control. Tomquelski and Martins [56] reported over $80 \%$ FAW larval mortality from Spinosad in two applications, the first at $15 \mathrm{DAE}$ applied to maize and the second 7 days afterwards. The difference in percentage here compared to the present study results could be attributed to the active ingredient type and rates at which pesticides cited from literature were applied to control the FAW. This does not make Ampligo ineffective for the reason that rates may be low but active ingredient in the chemical may be more potent than that of the chemicals cited from literature in this write-up. Also, Adamczyk et al. [57] have concluded on the effectiveness of Methoxyfenozide, L-cyhalothrin, Thiodicarb, Chlorfenapyr, and Emamectin benzoate use against FAW control. It must be emphasised here that the highest rate of Ampligo had greater impact on the FAW population. Similarly, the drop in FAW density on the control plot was $28.03 \%$ compared to the treated maize. Although the percentage drop on the control plot was less than that on the treated plots, the damage cause was significantly higher, probably because the heavy presence of the FAW infestation on the control plots was much felt compared to the treated maize plots, which showed a higher reduction in FAW over the growing period.

Meanwhile, over the maize growing period, that is, from 28 to 63 days after germination, FAW density declined to almost undetectable levels. Infestation was observed to be very critical during the first three weeks after germination. Therefore, applying Ampligo during the heavy infestation periods to deal with the high density of FAW is most critical. This critical stage happens to occur at the early vegetative growth phase in the life cycle of maize, where it is most susceptible to the FAW due to its succulent and juicy nature.

4.3. Fall Armyworm Effect on Maize Yield. Fall armyworm and its impact on maize yield have been reported by many researchers across the world, more specifically in countries where the pest has devastated vast maize fields and also caused a major yield reduction through its activities [2]. It is said that the larvae of the pest cause the biggest damage, which is reported to reduce yield by $6 \%$ in maize [3-5]. Also, in Brazil, the potential for yield losses in maize caused by the FAW is reported to range from 17 to $38.7 \%$ [58].

The present study, however, showed that 4 larvae/maize were found on each maize that grew on the experimental field before the chemical application (Ampligo), indicating that had it not been for the Ampligo application, the maize would not have survived the attack that came from FAW. Also, this further indicates that, without Ampligo application, a maize growing at a population density of 2000 maize/ha is likely to be infested with 8000 larvae of FAW depending on the prevailing climatic conditions. By this finding, it is worth emphasising that controlling the pest at its early stages with Ampligo is very critical for achieving good yield.
Our current finding based on the field efficacy test performed on Ampligo pesticides against FAW showed that there was no impact of the larvae on maize yield. Thus, maize plots that were treated with Ampligo at rates of $200 \mathrm{ml} / \mathrm{ha}$ and $240 \mathrm{ml} / \mathrm{ha}$ had less density of FAW, which even reduced to undetectable levels compared to maize on the control plots. Despite the high density of FAW found on the control maize plots, yields recorded were close to those of the treated plots. This no impact of the FAW on both treated and untreated maize plots could be attributed to other factors of maize production apart from pest control. These other factors include the type of maize seed, natural insect enemies to FAW, and nutrient and water availability.

We strongly agree here that all these conditions might have played a role in protecting the maize against FAW attack despite the Ampligo application. For instance, large numbers of different natural enemies were found on both treated and untreated plots and this could have played a very significant role in combating the FAW as evident especially on the control plots, which had no chemical application. This reemphasises the need for African countries to embrace biological pest control methods [14]. The variety used for the trial, Pioneer hybrid, is a superior variety with high vigour, which might have allowed maize to recover, once FAW population declined as evident on the treated maize plots. Also, as it is well established that water stress is a major factor in maize production and once this is removed, maize can achieve their highest potential. Finally, the adequate fertilizer (NPK and Urea) application regime ensured that maize received the required nutrition to yield well. Thus, good nutrient management resulted in healthy plant growth and thus maize being able to overcome damage by the pest $[59,60]$.

4.4. Ampligo Risk Assessment and Insect Diversity. The wrong use or ineffective application of any insecticide including Ampligo can cause harm to beneficial insect populations, which could lead to increased pest population pressure and greater damage to crops. Also, the fear of unacceptable impacts to human health is raised [61].

These queries about the use of insecticides have risen probably because the African marketplace for insecticide sale has become complex. Majority of the markets are flooded with unlabelled and unregistered materials, which may be hazardous to the environment when used by smallholder farmers [62, 63]. These illegal chemicals found at the marketplace are not risk-assessed and even regulatory bodies who are mandated to phase out these highly hazardous compounds and replace them with economic, efficacious, and lower-risk chemicals lack the capacity.

For the current study which looked into the efficacy of Ampligo against FAW infestation in Ghana, risk assessment was carried out during the time of the trial. Considering the treated and untreated plots, a number of nontarget organisms were sampled (Table 4). This included beneficial insects which were mainly predators and observed preying on FAW. This possibly contributed to reducing the population density of the target pest on all plots, especially the control plots. The high numbers of ants and spiders on the control plots can be 
exploited in designing an integrated pest management (IPM) for FAW controls. From this, one can infer that, despite the Ampligo pesticide application, the insect ecosystem was kept intact as evidenced by the $22 \%$ and $24 \%$ nontarget organism sampled on maize plots treated with $200 \mathrm{ml} /$ ha and $240 \mathrm{ml} / \mathrm{ha}$ rates, respectively. This further means that Ampligo can be classified as a lower-risk pesticide. SIMPSON's index of diversity estimated for the diversity of insect in the entire trial area as $60.02 \%$ indicated that the study area is a bit diverse in terms of the fauna counted during the bioefficacy of Ampligo against FAW. This creates a more homogenous ecosystem for IPM exploitation as indicated earlier taking into consideration the beneficial insects recorded under the study. Here, it is worth noting that the presence of nontarget organisms, especially predators, which were resident on the maize during and after insecticide application, is an indication that Ampligo may not be affecting their populations. The difference in the densities of natural enemies on treated and untreated plots could be attributed to differences in prey populations rather than Ampligo. Finally, the phytotoxic level monitored on maize was very low for Ampligo rates at $200 \mathrm{ml} / \mathrm{ha}$ and $240 \mathrm{ml} / \mathrm{ha}$, indicating that Ampligo applied did not impede chlorophyll development in the leaf, the main photosynthetic organ responsible for assimilating production.

\section{Conclusions}

The rates of $200 \mathrm{ml} / \mathrm{ha}$ and $240 \mathrm{ml} /$ ha of Ampligo applied to control FAW caused a significant reduction in the population of FAW on maize. The applied Ampligo rate of $240 \mathrm{ml} /$ ha gave a better protection to maize to yield higher fresh grain yield while $200 \mathrm{ml} /$ ha protected maize to give higher dry grain yield but differences were not statistically significant. Although the effect of the two Ampligo rates did not emerge for yields, it did emerge for number of FAW and damage incidence. Thus, the rates of 200 and $240 \mathrm{ml} /$ ha reduced damage incidence in treated maize compared to the nontreated. Aside from this, nontarget organisms were abundant and diverse at the study site despite the application of Ampligo, implying that activities of natural enemies such as spiders and ants found on both treated maize and nontreated maize plots contributed to reducing the FAW population. In conclusion, the use of Ampligo as a plant protection product against maize FAW in the trial caused a drastic reduction in FAW population and this manifested as low damage incidence on maize leaves. Regardless of the rate of application, Ampligo proved to be environmentally friendly to insects ecosystem, without any distraction to their population, when tested under field conditions in the coastal savannah environment of Ghana. This characteristic, therefore, qualifies the chemical to be released by the appropriate authorities onto the Ghanaian agrochemical market place. Taking this decision will allow the chemical to reach end-users for application on their maize farms to reduce FAW damage for maize to increase its grain yields.

\section{Data Availability}

The data used to support the findings of this study are available upon request.

\section{Conflicts of Interest}

The authors declare that they have no conflicts of interest.

\section{Acknowledgments}

The authors acknowledge Syngenta AG and RMG agrochemical suppliers for making this trial possible, especially Syngenta AG for providing funding and supplies for this trial. The authors are grateful to Professor Kenneth E. Danso, Director of BNARI, for allowing this trial work at the BNARI research field. Thanks are also due to Professor Daniel K. Asare for allowing the trials to be carried out on his irrigated research field. The assistance of Mr. Joseph Nunoo and Caleb Awuku during the data collection stage is hereby acknowledged. The authors also thank technicians Albert Nkumsah and Charles Asante of Radiation, Entomology and Pest Management Center (REPMC), for helping with sample preparation in the laboratory and Abraham Tetteh and Nehemiah Naanie, farm hands at REPMC, for their enormous assistance in the herbicide and insecticide (Lumax and Ampligo, respectively) application as well as fertilizer application and monitoring of irrigation schedules during this research (thus Ampligo application).

\section{References}

[1] B. M. Prasanna, J. E. Huesing, R. Eddy, and M. V. Peschke, Fall Armyworm in Africa: A Guide for Integrated Pest Management A Guide for Integrated Pest Management, CIMMYT, Mexico, 1st edition, 2018.

[2] A. H. Rose, R. H. Silversides, and O. H. Lindquist, "Migration flight by an aphid, Rhopalosiphum maidis (Hemiptera: Aphididae), and a noctuid, Spodoptera frugiperda (Lepidoptera: Noctuidae)," The Canadian Entomologist, vol. 107, no. 6, pp. 567-576, 1975.

[3] G. Goergen, P. L. Kumar, S. B. Sankung, A. Togola, and M. Tamò, "First report of outbreaks of the fall armyworm Spodoptera frugiperda (JE Smith) (Lepidoptera, Noctuidae) a new alien invasive pest in West and Central Africa," PLoS One, vol. 11, no. 10, pp. 1-9, Article ID e0165632, 2016.

[4] G. D. Buntin, "A review of plant response to fall armyworm, spodoptera frugiperda (J. E. Smith), injury in selected field and forage crops," Florida Entomologist, vol. 69, no. 3, pp. 549-559, 1986.

[5] W. P. Williams, P. M. Buckley, and C. A. Daves, "Identifying resistance in corn to southwestern corn borer (Lepidoptera: crambidae), fall armyworm (Lepidoptera: Noctuidae), and corn earworm (Lepidoptera: Noctuidae)," Journal of Agricultural and Urban Entomology, vol. 23, pp. 87-95, 2006.

[6] B. Wiseman and N. Widstrom, "Fall armyworm damage ratings on corn at various infestation levels and plant development stages," Journal of Agricultural Entomology, vol. 1, pp. 115-119, 1984.

[7] X. Ni, W. Xu, M. H. Blanco, and W. P. Williams, "Evaluation of fall armyworm resistance in maize germplasm lines using visual leaf injury rating and predator survey," Insect Science, vol. 21, no. 5, pp. 541-555, 2014.

[8] F. Huang, J. A. Qureshi, R. L. Meagher et al., "Cry1F resistance in fall armyworm Spodoptera frugiperda: single gene versus pyramided Bt maize," PLoS One, vol. 9, p. 10, Article ID e112958, 2014. 
[9] R. J. Horikoshi, D. Bernardi, O. Bernardi et al., "Effective dominance of resistance of Spodoptera frugiperda to Bt maize and cotton varieties: implications for resistance management," Scientific Reports, vol. 6, no. 1, Article ID 34864, 2016.

[10] P. Viana and P. Guimarães, "Maize resistance to the lesser cornstalk borer and fall armyworm in Brazil in Embrapa Milho e Sorgo-Artigo em anais de congresso (ALICE)," in Proceedings of the International Symposium on Insect Resistant Maize: Recent Advances and Utilization, 1994, Mexico, pp. 112-116, CIMMYT, Mexico, 1994.

[11] P. A. Viana, P. D. O. Guimaraes, I. D. S. Goncalves, and C. D. S. Magalhaes, "Resistência nativa de híbridos experimentais de milho à Spodoptera frugiperda," in Embrapa Milho e Sorgo-Artigo em anais de congresso (ALICE), Congresso nacional de milho e sorgo, 30.; simpósio sobre lepdópteros comuns a milho, soja e algodão, 1., 2014. Salvador. Eficiência nas cadeias produtivas e o abastecimento global: resumos expandidos, Sete Lagoas: Associação Brasileira de Milho e Sorgo, Salvador, Brazil, 2014.

[12] P. DeBach, "The scope of biological control," in Biological Control of Insect Pest and Weeds, pp. 3-20, Chapman \& Hall, London, UK, 1964.

[13] M. L. C. Figueiredo, I. Cruz, A. M. P. Dias, and R. B. Silva, "Interaction between baculovirus spodoptera and natural enemies on the suppression of Spodoptera frugiperda (J. E. Smith) (Lepidoptera: Noctuidae) in maize," Revista Brasileira de Milho e Sorgo, vol. 8, no. 3, pp. 207-222, 2009.

[14] R. L. Meagher, G. S. Nuessly, R. N. Nagoshi, and M. M. HayRoe, "Parasitoids attacking fall armyworm (Lepidoptera: Noctuidae) in sweet corn habitats," Biological Control, vol. 95, pp. 66-72, 2016.

[15] M. Rezende, T. Della Lucia, and I. Cruz, "Comportamento de lagartas de Spodopetra frugiperda (Lepidoptera, Noctuidae) parasitadas por chelonus insularis (Hymenoptera, Braconidae), sobre plantas de milho', Embrapa Milho e Sorgo-Artigo em periódico indexado (ALICE)," 1995.

[16] G. Barrera, O. Simón, L. Villamizar, T. Williams, and P. Caballero, "Spodoptera frugiperda multiple nucleopolyhedrovirus as a potential biological insecticide: genetic and phenotypic comparison of field isolates from Colombia," Biological Control, vol. 58, no. 2, pp. 113-120, 2011.

[17] R. W. Behle and H. J. R. Popham, "Laboratory and field evaluations of the efficacy of a fast-killing baculovirus isolate from Spodoptera frugiperda," Journal of Invertebrate $\mathrm{Pa}$ thology, vol. 109, no. 2, pp. 194-200, 2012.

[18] J. Gómez, J. Guevara, P. Cuartas, C. Espinel, and L. Villamizar, "Microencapsulated Spodoptera frugiperda nucleopolyhedrovirus: insecticidal activity and effect on arthropod populations in maize," Biocontrol Science and Technology, vol. 23, pp. 829-846, 2013.

[19] S. Haase, A. Sciocco-Cap, and V. Romanowski, "Baculovirus insecticides in Latin America: historical overview, current status and future perspectives," Viruses, vol. 7, no. 5, pp. 2230-2267, 2015.

[20] F. Moscardi, "Assessment of the application of baculoviruses for control of Lepidoptera," Annual Review of Entomology, vol. 44, no. 1, pp. 257-289, 1999.

[21] T. Alves, G. Cruz, V. Wanderley-Teixeira et al., "Effects ofPiper hispidinervumon spermatogenesis and histochemistry of ovarioles ofSpodoptera frugiperda," Biotechnic \& Histochemistry, vol. 89, no. 4, pp. 245-255, 2014.

[22] J. Fargues and N. K. Maniania, "Variabilité de la sensibilité despodoptera littoralis [Lep.: Noctuidae] a l'hyphomycete entomopathogène Nomuraea rileyi," Entomophaga, vol. 37, no. 4, pp. 545-554, 1992.

[23] S. P. Wraight, M. E. Ramos, P. B. Avery, S. T. Jaronski, and J. D. Vandenberg, "Comparative virulence of Beauveria bassiana isolates against lepidopteran pests of vegetable crops," Journal of Invertebrate Pathology, vol. 103, no. 3, pp. 186-199, 2010.

[24] L. C. Garcia, C. G. Raetano, and L. G. Leite, “Application technology for the entomopathogenic nematodes Heterorhabditis indica and Steinernema sp. (Rhabditida: heterorhabditidae and Steinernematidae) to control Spodoptera frugiperda (Smith) (Lepidoptera: Noctuidae) in corn," Neotropical Entomology, vol. 37, no. 3, pp. 305-311, 2008.

[25] H. K. Kaya, M. M. Aguillera, A. Alumai et al., "Status of entomopathogenic nematodes and their symbiotic bacteria from selected countries or regions of the world," Biological Control, vol. 38, no. 1, pp. 134-155, 2006.

[26] J. Molina-Ochoa, R. Lezama-Gutierrez, J. J. Hamm, B. R. Wiseman, and M. Lopez-Edwards, "Integrated control of fall armyworm (Lepidoptera: Noctuidae) using resistant plants and entomopathogenic nematodes (Rhabditida: steinernematidae)," Florida Entomologist, vol. 82, no. 2, pp. 263-271, 1999.

[27] A. S. Negrisoli, M. S. Garcia, C. R. C. Barbosa Negrisoli, D. Bernardi, and A. da Silva, "Efficacy of entomopathogenic nematodes (Nematoda: rhabditida) and insecticide mixtures to control Spodoptera frugiperda (Smith, 1797) (Lepidoptera: Noctuidae) in corn crops," Crop Protection, vol. 29, no. 7, pp. 677-683, 2010.

[28] A. S. Negrisoli Jr., M. S. Garcia, and C. R. C. Barbosa Negrisoli, "Compatibility of entomopathogenic nematodes (Nematoda: rhabditida) with registered insecticides for Spodoptera frugiperda (Smith, 1797) (Lepidoptera: Noctuidae) under laboratory conditions," Crop Protection, vol. 29, no. 6, pp. 545-549, 2010.

[29] M. R. Barreto, L. L. Loguercio, F. H. Valicente, and E. Paiva, "Insecticidal activity of culture supernatants from Bacillus thuringiensis Berliner strains against Spodoptera frugiperda Smith (Lepidoptera: Noctuidae) larvae," Anais da Sociedade Entomológica do Brasil, vol. 28, no. 4, pp. 675-685, 1999.

[30] D. M. Fontana Capalbo, F. H. Valicente, I. D. Oliveira Moraes, and L. H. Pelizer, "Solid-state fermentation of Bacillus thuringiensis tolworthi to control fall armyworm in maize," Electronic Journal of Biotechnology, vol. 4, pp. 9-10, 2001.

[31] R. Monnerat, E. Martins, P. Queiroz et al., "Genetic variability of Spodoptera frugiperda Smith (Lepidoptera: Noctuidae) populations from Latin America is associated with variations in susceptibility to Bacillus thuringiensis Cry toxins," Applied and Environmental Microbiology, vol. 72, no. 11, pp. 70297035, 2006.

[32] R. A. Polanczyk, R. F. P. D. Silva, and L. M. Fiuza, "Effectiveness of Bacillus thuringiensis strains against Spodoptera frugiperda (Lepidoptera: Noctuidae)," Brazilian Journal of Microbiology, vol. 31, no. 3, pp. 164-166, 2000.

[33] S. M. B. Silva, J. O. Silva-Werneck, R. Falcao et al., "Characterization of novel Brazilian Bacillus thuringiensis strains active against Spodoptera frugiperda and other insect pests," Journal of Applied Entomology, vol. 128, no. 2, pp. 102-107, 2004.

[34] P. C. Stevenson, G. C. Kite, G. P. Lewis et al., "Distinct chemotypes of Tephrosia vogelii and implications for their use in pest control and soil enrichment," Phytochemistry, vol. 78, pp. 135-146, 2012. 
[35] K. A. G. Wyckhuys and R. J. O’Neil, “Influence of extra-field characteristics to abundance of key natural enemies of Spodoptera frugiperda Smith (Lepidoptera: Noctuidae) in subsistence maize production," International Journal of Pest Management, vol. 53, no. 2, pp. 89-99, 2007.

[36] K. A. G. Wyckhuys and R. J. O’Neil, “Social and ecological facets of pest management in Honduran subsistence agriculture: implications for IPM extension and natural resource management," Environment, Development and Sustainability, vol. 12, no. 3, pp. 297-311, 2010.

[37] M. Mugisha-Kamatenesi, A. Deng, J. Ogendo et al., "Indigenous knowledge of field insect pests and their management around Lake Victoria basin in Uganda," African Journal of Environmental Science and Technology, vol. 2, pp. 342-348, 2008.

[38] J. O. Ogendo, A. Deng, E. Omollo, J. Matasyoh, R. Tuey, and Z. Khan, "Management of stem borers using selected botanical pesticides in a maize-bean cropping system," Egerton Journal of Science and Technology, vol. 13, pp. 21-38, 2015.

[39] P. C. Stevenson, M. B. Isman, and S. R. Belmain, "Pesticidal plants in Africa: a global vision of new biological control products from local uses," Industrial Crops and Products, vol. 110, pp. 2-9, 2017.

[40] E. A. Martin, B. Seo, C.-R. Park, B. Reineking, and I. SteffanDewenter, "Scale-dependent effects of landscape composition and configuration on natural enemy diversity, crop herbivory, and yields," Ecological Applications, vol. 26, no. 2, pp. 448-462, 2016.

[41] L. Pumariño, G. W. Sileshi, S. Gripenberg et al., "Effects of agroforestry on pest, disease and weed control: a metaanalysis," Basic and Applied Ecology, vol. 16, pp. 573-582, 2015.

[42] C. A. O. Midega, J. O. Pittchar, J. A. Pickett, G. W. Hailu, and Z. R. Khan, "A climate-adapted push-pull system effectively controls fall armyworm, Spodoptera frugiperda (J E Smith), in maize in East Africa," Crop Protection, vol. 105, pp. 10-15, 2018.

[43] H. Obeng, Soil Classification in Ghana, Selected Economic Issues in Ghana, Centre for Poilicy Analysis (CEPA), CEPA, Accra, Ghana, 2000.

[44] J. O. Frimpong, H. M. Amoatey, E. O. Ayeh, and D. K. Asare, "Productivity and soil water use by rainfed maize genotypes in a coastal savannah environment," International Agrophysics, vol. 25, pp. 123-129, 2011.

[45] J. O. Frimpong, M. Q. Addy, E. O. Ayeh et al., "Field assessment of soil water storage and actual evapotranspiration of rainfed maize (Zea mays L.) genotypes in a coastal savannah environment," Open Journal of Soil Science, vol. 2, no. 3, pp. 213-222, 2012.

[46] F. M. Davis, S. Ng, and W. Williams, Visual Rating Scales for Screening Whorl-Stage Corn for Resistance to Fall Armyworm, Technical bulletin-Mississippi Agricultural and Forestry Experiment Station, USA, 1992.

[47] J. Lauer, "Methods for calculating corn yield," 2002, http:// corn.agronomy.wisc.edu/AA/pdfs.

[48] A. E. Magurran, Ecological Diversity and Its Measurement, Princeton University Press, Princeton, NJ, USA, 1988.

[49] F. M. Davis, W. P. Williams, and P. M. Buckley, "Growth responses of southwestern corn borer (Lepidoptera: crambidae) and fall armyworm (Lepidoptera: Noctuidae) larvae fed combinations of whorl leaf tissue from a resistant and a susceptible maize hybrid," Journal of Economic Entomology, vol. 91, no. 5, pp. 1213-1218, 1998.
[50] J. M. Labatte, "Within-plant distribution of fall armyworm (Lepidoptera: Noctuidae) larvae on corn during whorl-stage infestation," Florida Entomologist, vol. 76, no. 3, pp. 437-447, 1993.

[51] J. R. Young, "Fall armyworm: control with insecticides," Florida Entomologist, vol. 62, no. 2, pp. 130-133, 1979.

[52] B. J. Fitzpatrick, R. N. Mascarenhas, M. L. Boyd, D. J. Boethel, E. Burris, and D. Cook, "Soybean looper and beet armyworm control on soybean in Louisiana, 1995," Arthropod Management Tests, vol. 21, no. 1, pp. 289-291, 1996.

[53] D. R. Cook, B. R. Leonard, and J. Gore, "Field and laboratory performance of novel insecticides against armyworms (Lepidoptera: Noctuidae)," Florida Entomologist, vol. 87, no. 4, pp. 433-439, 2004.

[54] F. A. De Albuquerque, L. M. Borges, T. D. O. Iacono, N. C. D. S. Crubelati, and A. D. C. Singer, "Eficiência de inseticidas aplicados em tratamento de sementes e em pulverização, no controle de pragas iniciais do milho," Revista Brasileira de Milho e Sorgo, vol. 5, pp. 15-25, 2010.

[55] G. V. Tomquelski and G. L. M. Martins, "Eficiência de inseticidas sobre Spodoptera frugiperda (JE Smith, 1797) (Lepidoptera: Noctuidae) em milho na região dos Chapadões," Revista Brasileira de Milho e Sorgo, vol. 6, pp. 26-39, 2010.

[56] J. J. Adamczyk, B. R. Leonard, and J. B. Graves, “Toxicity of selected insecticides to fall armyworms (Lepidoptera: Noctuidae) in laboratory bioassay studies," Florida Entomologist, vol. 82, no. 2, pp. 230-236, 1999.

[57] O. D. Fernandes, J. R. P. Parra, A. F. Neto, R. Pícoli, A. F. Borgatto, and C. G. B. Demétrio, "Efeito do Milho Geneticamente Modificado Mon810 sobre a Lagarta-doCartucho Spodoptera frugiperda (J. E. Smith, 1797) (Lepidoptera: Noctuidae)," Revista Brasileira de Milho e Sorgo, vol. 2, no. 2, pp. 25-35, 2003.

[58] M. A. Altieri and C. I. Nicholls, "Soil fertility management and insect pests: harmonizing soil and plant health in agroecosystems," Soil and Tillage Research, vol. 72, no. 2, pp. 203-211, 2003.

[59] H. Morales, I. Perfecto, and B. Ferguson, "Traditional fertilization and its effect on corn insect populations in the Guatemalan highlands," Agriculture, Ecosystems \& Environment, vol. 84, no. 2, pp. 145-155, 2001.

[60] J. Pretty and Z. Bharucha, "Integrated pest management for sustainable intensification of agriculture in Asia and Africa," Insects, vol. 6, no. 1, pp. 152-182, 2015.

[61] H. De Bon, J. Huat, L. Parrot et al., "Pesticide risks from fruit and vegetable pest management by small farmers in subSaharan Africa: a review," Agronomy for Sustainable Development, vol. 34, no. 4, pp. 723-736, 2014.

[62] C. E. Donald, R. P. Scott, K. L. Blaustein et al., "Silicone wristbands detect individuals' pesticide exposures in West Africa," Royal Society Open Science, vol. 3, p. 433, Article ID 160433, 2016.

[63] P. C. Jepson, M. Guzy, K. Blaustein et al., "Measuring pesticide ecological and health risks in West African agriculture to establish an enabling environment for sustainable intensification," Philosophical transactions of the Royal Society of London. Series B, Biological Sciences, vol. 369, p. 18, Article ID 20130491, 2014. 